\title{
Market Structure and Development Potential of Organic Products in the World and Turkey
}

\author{
Şule Turhan and Burcu Erdal
}

\begin{abstract}
Organic agriculture is an approach that integrates human, environment and economically sustainable agricultural production system. It can be considered an alternative for world and Turkish agriculture. It can be seen that organic agriculture has been affected by the general problems of our agriculture. The most important problems of our agriculture are organization and marketing. The development of the organic farming and organic product market in our country has begun with the request of the enterprises operating in Europe for the 1980's. The quality of products produced by our country and the diversity of the products are important considerations. The production of organic agricultural products, which started with the contracted farming system in Turkey, has begun to be supported by the production methods realized with independent projects after the endeavors of demand creation efforts such as traditional products. The fact that organic agriculture can continue to increase in Turkey, the return of investment, the reduction of costs, and the increase in domestic and foreign market demand for products. It is especially important to monitor the technological developments that are taking place in the world and to reflect the gains that will be obtained there from the export of organic agriculture products.
\end{abstract}

Keywords - Turkey, organic, marketing, development.

\section{INTRODUCTION}

Organic agriculture can be defined as; an integrated farming system that strives for sustainability, the enhancement of soil fertility and biological diversity whilst, with rare exceptions, prohibiting synthetic pesticides, antibiotics, synthetic fertilizers, genetically modified organisms, and growth hormones [1]. Organic farming is the subject of extensive research in northern countries, especially in Europe. A wide range of studies [2,3,4] have demonstrated the advantageous aspects of this system in terms of ecosystem functioning, soil fertility conservation and economic impact. NGOs and farmers' groups are increasingly adopting organic techniques as a method of improving productivity and food security in these systems.

Istatistic depicts the global sales of organic food from 1999 to 2017. According to the report, worldwide net sales of organic food amounted to approximately 97 billion U.S. dollars in 2017, up from 80 billion U.S. dollars the previous year. As global organic foods sales increase each each, so does the area of organic farming land. In 2017, organic farming was spread across 70 million hectares of land, with Australia accounting for

Şule Turhan, Assoc. Prof. Dr. Bursa Uludag University, Agricultural Faculty, Department of Agricultural Economics Bursa, Turkey.

Burcu Erdal, Dr. Bursa Uludag University, Agricultural Faculty, Department of Agricultural Economics, Bursa, Turkey . almost 35.7 million hectares of the organic producing countries [5].

The market for organic goods in Turkey is small but growing. Organic production in Turkey started in the 1980s in the Aegean region due to a demand for organic goods in Europe. Since then, organic production and consumption in Turkey have increased each year. The first organic products produced in Turkey were Sultana grapes. Today there are more than 200 kinds of agricultural products produced organically in Turkey. Most of the organic production in Turkey is intended for export. The European Union is the largest export market for Turkish organic goods, but the United States, Canada, Australia, Iraq, Switzerland and Japan also import organic products from Turkey. In this study, marketing of organically produced products in Turkey will be examined and problems will be addressed.

\section{DESCRIPTION}

Organic farming works in harmony with nature rather than against it. This involves using techniques to achieve good crop yields without harming the natural environment or the people who live and work in it. The methods and materials that organic farmers use are summarised as Table1 [6].

TABLE I: METHODS AND MATERIALS THAT ORGANIC FARMERS USE

\begin{tabular}{|l|l|l|}
\hline $\begin{array}{l}\text { To keep and build } \\
\text { good soil structure } \\
\text { and fertility }\end{array}$ & $\begin{array}{l}\text { To control pests, } \\
\text { diseases and weeds }\end{array}$ & $\begin{array}{l}\text { Organic farming also } \\
\text { involves }\end{array}$ \\
\hline $\begin{array}{l}\text { Recycled and } \\
\text { composted crop wastes } \\
\text { and animal manures }\end{array}$ & $\begin{array}{l}\text { Careful planning and } \\
\text { crop choice }\end{array}$ & $\begin{array}{l}\text { Careful use of water } \\
\text { resources }\end{array}$ \\
\hline $\begin{array}{l}\text { The right soil } \\
\text { cultivation at the right } \\
\text { time }\end{array}$ & $\begin{array}{l}\text { The use of resistant } \\
\text { crops }\end{array}$ & $\begin{array}{l}\text { Good animal } \\
\text { husbandry }\end{array}$ \\
\hline $\begin{array}{l}\text { Crop rotation } \\
\text { Green manures and } \\
\text { legumes }\end{array}$ & $\begin{array}{l}\text { Good cultivation } \\
\text { practice }\end{array}$ & Crop rotation \\
\hline $\begin{array}{l}\text { Mulching on the soil } \\
\text { surface }\end{array}$ & $\begin{array}{l}\text { Encouraging useful } \\
\text { predators that eat pests }\end{array}$ & $\begin{array}{l}\text { Increasing genetic } \\
\text { diversity }\end{array}$ \\
\hline & Using natural pesticides & \\
\hline
\end{tabular}

Source: [7].

\section{ORGANIC PRODUCTS MARKET}

\section{A. World}

Demand for organic products is growing rapidly, with market share in the US, Europe and other developing countries around the world being quite small [8]. According to the year of 2017, 
organic agriculture is practiced in 172 countries, and 43.7 million hectares of agricultural land are managed organically by approximately 2.9 million farmers. The global sales of organic food and drink reached 97 billion US dollars in 2017 [9] Thirty six percent of the world's organic producers are in Asia, followed by Africa (28\%) and Europe (14\%).

If we will evaluate the European Union countries; In 2017, the German organic market increased by $5.9 \%$. In 2017, the US organic market grew by $6.4 \%$ to 40 million Euro. In the United States, compared to 1997, the market has increased tenfold. There is a lot of demand for organic food in France and the market is experiencing constant growth. Compared to the previous year, sales increased by $18 \%$ in 2017 . At least 10 consumers prefer to buy organic products at least occasionally, while 6 consumers use their preference once a month. In order to reach this demand, the number of organic producers has increased. One in four of the milk purchased is organic in Denmark. In 2017, the Swedish organic market reached a market share of $9.3 \%$. The highest demand was in the fruit and vegetable product group. In 2017, the Swiss organic market increased by $8.1 \%$. Thus, per capita consumption of organic products increased to 315 Swiss francs (287 euros in 2017). This is the highest figure in Europe. One of the 5 hectares in the mountainous region in the country is processed organically [10]. The development of organic farming areas in EU Member States is given in Table 2. The area of organic production in the
EU was 4,861,579 hectares in 2002 and 12.189 .814 hectares in 2017. Increased by $110.5 \%$. The annual growth rate of the organic farming area of the 28 member states of the EU is $6.1 \%$ for 2016. The rate of increase for 2017 is $6.2 \%$. In 2019 the organic agricultural land in Europe increased by 845232 hectares and there were more than 370000 organic producers in Europe and almost 300000 in European Union [7]. The U.S. organic market in 2018 broke through the $\$ 50$ billion mark for the first time, with sales hitting a record $\$ 52.5$ billion, up 6.3 percent from the previous year, according to the 2019 Organic Industry Survey released Friday by the Organic Trade Association.

Organic food sales reached $\$ 47.9$ billion, for an increase of 5.9 percent. Sales of organic non-food products jumped by 10.6 percent to $\$ 4.6$ billion. The growth rate for organic continued to easily outpace the general market: in 2018, total food sales in the U.S. edged up just 2.3 percent while total non-food sales rose 3.7 percent [11]. OTA's survey uncovers that America's 75 million Millennials are now devouring organic, and they're making sure their families are too. Parents in the 18- to 34-year-old age range are now the biggest group of organic buyers in America. This statistic shows the organic food retail sales share worldwide in 2017, broken down by country. According to the report, the United States accounted for approximately 43 percent of global organic retail sales that year.

TABLE II: DEVELOPMENT OF ORGANIC FARMING AREA AND NUMBER OF FARMERS IN EU MEMBER COUNTRIES BY YEARS

\begin{tabular}{|c|c|c|c|c|c|c|}
\hline Years & $\begin{array}{l}\text { Organic } \\
\text { production area } \\
\text { (hectare) (EU15) }\end{array}$ & $\begin{array}{l}\text { Organic } \\
\text { production area } \\
\text { (hectare) (EU25) }\end{array}$ & $\begin{array}{l}\text { Organic } \\
\text { production } \\
\text { area } \\
\text { (hectare) } \\
\text { (EU28) }\end{array}$ & $\begin{array}{l}\text { Number of } \\
\text { organic } \\
\text { farmers } \\
\text { (EU15) }\end{array}$ & $\begin{array}{l}\text { Number of } \\
\text { organic } \\
\text { farmers } \\
\text { (EU25) }\end{array}$ & $\begin{array}{l}\text { Number of } \\
\text { organic } \\
\text { farmers } \\
\text { (EU28) }\end{array}$ \\
\hline 2002 & 4.861 .579 & 4.861 .579 & 4.861 .579 & 140.066 & 140.066 & 140.066 \\
\hline 2003 & 5.038 .830 & 5.038 .830 & 5.038 .830 & 135.610 & 135.610 & 135.610 \\
\hline 2004 & 5.033 .091 & 5.643 .909 & 5.643 .909 & 129.313 & 141.237 & 141.237 \\
\hline 2005 & 5.257 .894 & 6.036 .950 & 6.036 .950 & 143.298 & 160.784 & 160.784 \\
\hline 2006 & 5.492 .964 & 6.457 .729 & 6.457 .729 & 154.308 & 176.184 & 176.184 \\
\hline 2007 & 5.775 .791 & 6.870 .823 & 7.120 .130 & 158.472 & 183.348 & 185.826 \\
\hline 2008 & 6.154 .359 & 7.332 .929 & 7.613 .816 & 164.263 & 193.610 & 196.639 \\
\hline 2009 & 6.639 .2561 & 7.959 .530 & 8.273 .308 & 172.692 & 205.238 & 208.762 \\
\hline 2010 & 7.088 .479 & 8.661 .792 & 9.018 .969 & 179.082 & 215.650 & 219.353 \\
\hline 2011 & 7.294 .961 & 9.020 .018 & 9.416 .664 & 186.720 & 226.494 & 236.943 \\
\hline 2012 & 7.580 .568 & 9.413 .147 & 9.868 .108 & 190.899 & 233.626 & 251.695 \\
\hline 2013 & 7.843 .937 & 9.739 .323 & 10.232 .949 & 194.743 & 240.044 & 258.773 \\
\hline 2014 & 8.431 .915 & 10.436 .177 & 10.849 .832 & 193.726 & 236.026 & 256.272 \\
\hline 2015 & 8.610 .481 & 10.628 .773 & 11.069 .132 & 207.083 & 248.262 & 269.111 \\
\hline 2016 & 9.457 .998 & 11.567 .355 & 12.047 .877 & 230.841 & 274.570 & 295.123 \\
\hline 2017 & 10.172 .930 & 12.328 .096 & 12.819 .814 & 244.020 & 286.992 & 305.394 \\
\hline
\end{tabular}

Source: [12]

Germany is the 2nd biggest organic market of the world with good prospects for U.S. organic products like salmon, tree nuts, fruits and vegetables, processed food products and others. The German organic market is heavenly depending on imports to 
meet consumer demands. The EU-U.S. Organic Equivalence arrangement has created new export opportunities for some U.S. companies. BioFach, the world's largest strictly organic trade fair, is held annually in Germany. China's domestic market in organic products began developing in the mid-2000s and has expanded very rapidly, especially in the past few years when stories of food scandals became prominent. Chinese organic consumers can be divided into eight main groups: white collar families; families with young children; families with health issues; overseas returnees; business people from Chinese Taipei and Hong Kong (China); government officials; young people; and foreigners living in China. White collar families, accounting for $40 \%$ of organic consumers, are the largest group.

In Japan, organic food and beverages are generally perceived as premium by Japanese consumers, and are still considered an unnecessary indulgence. Further contributing to the category's weak performance is the prolonged economic downturn, which has led consumers to cut their spending. Sales of organic beverages are largely generated by hot drinks, especially organic green tea, which accounted for a $56 \%$ share of value sales in 2014 [12].

\section{B. Turkey}

In our country, the organic agriculture market which is formed by the relations of import and export companies in contracted producers is gradually developed. Since 2000, sales centers have started to sell organic products. The increasing number of stores have become a point of education for consumers as well as marketing organic agricultural products. Today, organic products are sold in private stores and producer markets as well as in private supermarkets [13].

OTA estimates total organic market consumer sales of Turkey at about $\$ 119$ million USD per year. The total market size for organic packaged food and beverages in Turkey in 2018 is US\$ $142 \mathrm{mn}$, making it the 23rd largest market in the world by value. Per capita spending on organic packaged food and beverages in Turkey is US\$1.3, which ranks as the 33rd largest spending per capita in the world. Organic packaged food and beverages in Turkey will see strong year-on-year growth of close to $15 \%$ in 2015. This is much faster than the rest of the Western Europe region, which will experience greater than $4 \%$ year-on-year growth in 2015. Turkey maintains a market size for organic packaged food and beverages of US\$97.9mn in 2015 , which is $0.3 \%$ of global category sales. Within the Western Europe region, Germany, France, the UK, Italy, Denmark, the Netherlands, Sweden, Switzerland, and Spain all surpass Turkey in value sales of organic packaged food and beverages. Starting from a low base, Turkey will experience strong forecast growth of sales of organic packaged food and beverages, at $12.9 \%$ from 2015-2020. Organic packaged food and beverages are premium-priced in Turkey, and are mainly purchased by educated, high-income urban consumers. Increasing health consciousness and skepticism of genetically modified organisms (GMOs) drove substantial growth in the sales of organic food and beverages in recent years, albeit from a low base. Organic rice is the leading organic food in Turkey in terms of sales value [14]. Organic black tea accounts for the majority of organic beverage sales in the market. Most of the organic production in Turkey is intended for export. The European Union is the largest export market for Turkish organic goods, but the United States, Canada, Australia, Iraq, Switzerland and Japan also import organic products from Turkey. In 2016, Turkey exported around \$14 million of organic products to the United States, primarily organic soybeans and organic corn. Turkish organic exports to the United States from Jan - Nov 2016 were up 113 percent to \$31 million on the same period in 2014, mostly due to growth in organic corn, which is up 375 percent on Jan - Nov 2014 data. Organic farming is regulated by the Department of Good Agricultural Practices and Organic Farming within the General Directorate Plant Production in the Turkish Ministry of Food, Agriculture and Livestock (MinFAL). The first domestic regulation on organic farming in Turkey was put into place in 1994. In 2004, the new Organic Agriculture Law was put into force as a part of EU harmonization, and has been amended several times since then to reflect new EU regulations, most recently in 2012. In addition to comprehensive regulations on the production, sale, transport and trade of organic products, the 2004 law also established the Organic Farming Committee, a government regulatory committee, and the National Directing Committee of Organic Farming, an advisory committee to MinFAL. Made up of officials from several different government ministries, universities, the private sector, Professional organizations, and NGOs, the National Directing Committee meets at least twice a year to implement organic agricultural projects, raise awareness among consumers, identify problems in the certification process, and develop priorities for projects and research. The Organic Farming Committee regulates and monitors organic production, authorizes agencies to conduct organic certifying inspections, and receives the recommendations from the National Directing Committee. Despite the supports and efforts to promote organic production, domestic consumption and awareness of organic products remains relatively limited. Organic products are often viewed by consumers as a luxury item. Consumers of organic products in Turkey generally have higher income levels, are more educated, live in urban areas, and are more conscious of their health. Organic products are available in large urban supermarkets/hypermarkets, in organic bazaars, and, to a lesser extent, in specialty stores or on the internet. Most people in Turkey are not educated about the benefits of organic foods, and many consumers cannot distinguish organic products from conventional products. Consumers in Turkey often trust their local supermarkets' brands, and prefer to buy "what they know." The market for organic packaged food in Turkey reached $\$ 137.5$ million in 2018 and is expected to reach $\$ 170$ million by 2020. Sales of organic packaged food increased 13 percent from 2017 to 2018. Most of this growth was due to rising urbanization, improving economic conditions, and increasing availability of organic products. Organic dairy, baby food, and snack items are the most consumed organic products in Turkey. 
Organic cheese and olive oils have significant growth potential, particularly due to their importance in Turkish cuisine and promotional efforts within Turkey [14].

\section{CONCLUSION}

The organic agriculture movement is rapidly developing as an alternative to sustainable agriculture. Organic farming methods are widely used in underdeveloped and developing countries, largely because of ecomics and a lack of chemicals. However, they are becoming more widely accepted in developed countries as a reaction or factory conditions.

The marketing of organic products is not very different from traditional products. But the characteristics of organic products and the relevant characteristics of consumption of organic products also create differences in the strategies that producers will follow when marketing organic products. Production and marketing activities of organic products are independent and independent of each other. Production activities should be guided by the marketing and production should be done in accordance with the information obtained from the market. In this context, producer enterprises should meet the demands and expectations of consumers by carrying out market and marketing researches. The producers should analyze the competitors and competitors taking part in the market, taking into account that consumer trends and behaviors in the market are constantly changing. SWOT analyzes to assess their environmental conditions to reveal their strengths and weaknesses, market opportunities and threats.

\section{REFERENCES}

[1] https://en.wikipedia.org/wiki/Organic_farming

[2] Mader, P.; Fließbach, A.; Dubois D.; Gunst L.; Fried, P. and U. Niggli , Soil fertility and biodiversity in organic farming.- Science 2002. https://doi.org/10.1126/science.1071148

[3] Offermann F. and H. Nieberg, , Economic performance of organic farms in Europe.- Organic farming in Europe: Economics and Policy Volume 5. 2000. University of Hohenheim, Germany.

[4] Stolze, M.; Piorr, A.; Haring, A. and S. Dabbert, The environmental impacts of organic farming in Europe.- Organic farming in Europe: Economics and Policy, Volume 6. University of Hohenheim, Germany. 2000,Thompson.

[5] https://www.statista.com

[6] Anonim, What is Organic Farming?, HDRA, HDRA - the organic organisation. 1998.

[7] Anonim, The World of Organic Agriculture Statistics Emerging Trends 2018, FIBL, IFOAM.

[8] Thompson, B., Statistical Significance and Effect Size Reporting:Portrait of a Possible Future, ResearchiIn The Schools Mid-South Educational Research Association 1998, Vol. 5, No. 2, 33-38.

[9] http://www.organic-world.net

[10] https://www.biofach.de

[11] https://www.ota.com

[12] http://www.globalorganictrade.com

[13] Rehber, E., Organik Tarım Ekonomisi, Ekin Basım Yayım ISBN: 978-605-5335-14-4, 2011, Bursa

[14] Kilcher, L., How organic agriculture contributes to sustainable development, University of Kassel at Witzenhausen JARTS, Supplement 89 (2007) 31-49.

[15] Grow, S., C. Greene, Impact of International Organic Markets on Small US Producers, Contributed Paper Prepared for 105th EAAE, 2007.

[16] Surrett, J., Turkish Organic Market Overview, Global Agricultural Information Network, USDA Foreign Agricultural Services, 2016GAIN Report Number: TR6005. 